\title{
ASSESSMENT OF AGRICULTURAL CULTIVATION AND PRODUCTION IN DISTRICTS OF THE KASHMIR VALLEY
}

\author{
Altaf Hussain \\ Department of Geography, Jamia Millia Islamia, Central University and Department of \\ Regional Planning, School of Planning and Architecture, New Delhi.
}

DOI: 10.46609/IJSSER.2020.v05i07.010 URL: https://doi.org/10.46609/IJSSER.2020.v05i07.010

\begin{abstract}
Historically, agriculture has been viable and sustainable industry in the state of Jammu and Kashmir. It has traditionally been the predominant sector in the Kashmir valley which supports around above 70 per cent of its population. This region has its own specific geo-climatic condition, which determine the cropping pattern and its productivity. Allied activities like horticulture, dairy development, fisheries, livestock and sericulture also play significant role in the agriculture sector.This study is about the production and cultivation capacity of agriculture in the Kashmir valley. There has been tried to assess the existing agricultural yielding as well as the cultivation capacity of culturable land in this region. There are taken few selected indictors for this study in order to analyse the cultivation and production of agriculture in districts of the Kashmir valley.
\end{abstract}

Keywords: Agriculture, Cultivation, Production, Districts, Kashmir Valley, Region

\section{INTRODUCTION}

Agriculture accounts for 14 per cent of Gross Domestic Product (GDP) in India. It is the basic source of livelihood for the people living in rural areas (Planning Commission, 2012). There are contributed 36 percent of the net domestic product by agriculture and its allied sectors and support about 80 percent of the living population (Dixit, Sharma, \& Ali, 2014). Agricultural development is a multidimensional concept which incorporate a variety of aspects like agricultural land utilization, commercialization of agriculture, intensity of cropping, crop productivity, crop diversification and concentration and maintenance of ecological balance (Bhat, 2013). Although, the region-wise classification of productivity of agricultural land differs throughout the state of Jammu and Kashmir. The productivity of the land is found in the lower areas due to geographical barrier in the Ladakh region. Similarly, the situation in the Kashmir 


\section{International Journal of Social Science and Economic Research}

ISSN: $2455-8834$

Volume: 05, Issue: 07 "July 2020"

and Jammu region is absolutely reverse. Here the productivity of the land is on the higher areas. So, the productivity of the crops differs from region to region (Planning Commission, 2003). Intensification of agriculture needs to meet the demands generated by the living population and increasing incomes. This can cause to significant environmental impacts like depletion of water resources, deterioration of water quality, soil erosion, loss of biodiversity and climate change (Tilman, Cassman, Matsons, Naylor, \& Polasky, 2002).

The total area of the state is 24.15 lakh hectares as per 1992 census record of India. Out of this area, 138,6867 square kms are rural land and 305.4 square kms are urban land. It shows that the state of Jammu and Kashmir is rural in its characteristics with 6503 villages. Out of the total area of 24.15 lakh hectares, agricultural statistics are recorded for around 8.26 lakh hectares. The rest of the area is under forests and mountains (Raina, 2002). There are grown nearly 75 percent of temperate fruits in this state in India. The cultivated orchards produce fine quality of saffron, pears, apples, cherries, walnut, almond, strawberry, plums and so on. Horticulture industry earns 500 million Indian rupees yearly and provides job opportunities to thousands of people in the agricultural sector (Rather, Lone, Reshi, \& Mir, 2013). Horticulture industry of Kashmir valley is considered as the backbone of the rural economy in the Jammu and Kashmir state. There are grown 75 per cent of temperate fruits in this state. The cultivation of orchards gives fine quality of apples, pears, peaches, walnut, cherries, almond, saffron, strawberry, apricot and so on. The horticulture industry earns revenue of over 500 million Indian rupees yearly and produce job opportunities for the thousands of people in the agricultural sector (Sharma, Sharma, \& Waris, 2012). The horticulture sector plays an important role in the state of Jammu \& Kashmir in providing jobs and employment. However, the state is facing challenges in regard to the development of horticulture. It contains low productivity, higher percentage of off-grade fruit, variability in crops like walnut and almond, poor connectivity with the market place and small and fragmented land holdings (Planning Commission, 2003). Groundwater is the largest freshwater resource, which plays a significant role in socio-economic life of the people in terms of agricultural, domestic, horticultural and hydropower generation in the Kashmir valley (Jeelani, Shah, \& Hussain, 2014).

\section{STUDY AREA}

Kashmir valley is situated between the Pir Panjal and the Karakoram range in the Indian state of Jammu and Kashmir. It is also one of the regions of the Jammu and Kashmir state. The valley is encircled by mountain ranges characterized by snow covered high mountain peaks and has an area of 15,984 square kilometres. The total population of Kashmir valley is 6.908 million in the state of Jammu and Kashmir (Census of India, 2011). Jhelum and its tributaries are prominent rivers of the valley. The Kashmir valley consists of Budgam, Bandipore, Anantnag, Baramulla, 


\section{International Journal of Social Science and Economic Research}

ISSN: $2455-8834$

Volume: 05, Issue: 07 "July 2020"

Ganderbal, Kulgam, Pulwama, Kupwara, Shopian and Srinagardistricts. It is located between the coordinates of $73^{\circ} 55^{\prime} \mathrm{E}$ and $75^{\circ} 35^{\prime} \mathrm{E}$, and $35^{\circ} 25^{\prime} \mathrm{N}$ and $34^{\circ} 45^{\prime} \mathrm{N}$.

\section{OBJECTIVES}

To study and analyze the cultivation and production capacity of agriculture in districts of the Kashmir valley.

\section{DATABASE AND METHODOLOGY}

The aim of this study is to assess the existing agriculture of the Kashmir valley. The literature study has been done with the help of articles, journals, and other sources. Secondary sources have been used as a main source of database. There have been extracted and chosen few indicators from the census of India and from the census report of the directorate of economic and statistics, department of Jammu and Kashmir. The selected indicators are calculated and compared with the Kashmir valley average and state average. The software tool Arc Map has been used for preparing maps for this study. The selected indictors of this study are given below in table 1.

Table 2: Selected Indicators of Agriculture (2011-12)

\begin{tabular}{|c|c|c|c|c|c|c|c|c|c|}
\hline $\begin{array}{c}\text { S. } \\
\text { No. }\end{array}$ & $\begin{array}{c}\text { District } \\
\text { name }\end{array}$ & $\begin{array}{c}\text { Cultivabl } \\
\text { e area as } \\
\text { \% of } \\
\text { reporting } \\
\text { area }\end{array}$ & $\begin{array}{c}\text { Area under } \\
\text { commercial } \\
\text { crops as \% } \\
\text { of gross } \\
\text { area sown }\end{array}$ & $\begin{array}{c}\text { Net area } \\
\text { sown as } \\
\text { \% of } \\
\text { geograp } \\
\text { hical } \\
\text { area }\end{array}$ & $\begin{array}{c}\text { Total } \\
\text { share of } \\
\text { fresh and } \\
\text { dry fruit } \\
\text { productio } \\
\text { n (in \%) }\end{array}$ & $\begin{array}{c}\text { Total } \\
\text { share } \\
\text { of fish } \\
\text { product } \\
\text { ion (in } \\
\%)\end{array}$ & $\begin{array}{c}\text { Total } \\
\text { livestoc } \\
\mathrm{k} \\
\text { populati } \\
\text { on (in } \\
\text { lakh) }\end{array}$ & $\begin{array}{c}\text { Total } \\
\text { red } \\
\text { meat } \\
\text { producti } \\
\text { on (lakh } \\
\text { kg) }\end{array}$ & $\begin{array}{c}\text { Total } \\
\text { white } \\
\text { meat } \\
\text { producti } \\
\text { on (lakh } \\
\text { kg) }\end{array}$ \\
\hline 1 & Kupwara & 72.26 & 5.88 & 27.00 & 11.45 & 4.19 & 10.805 & 7.94 & 7.258 \\
\hline 2 & Badgam & 65.18 & 22.45 & 30.32 & 5.46 & 6.25 & 8.385 & 10.066 & 4.136 \\
\hline 3 & Baramulla & 63.94 & 27.86 & 54.00 & 31.46 & 21.96 & 16.297 & 19.542 & 9.31 \\
\hline 4 & Bandipora & 62.61 & 16.29 & 23.00 & 3.72 & 17.73 & 9.795 & 14.395 & 5.278 \\
\hline 5 & Srinagar & 71.06 & 23.82 & 22.00 & 1.73 & 10.53 & 2.279 & 2.854 & 1.284 \\
\hline 6 & Ganderbal & 50.12 & 19.76 & 13.20 & 3.09 & 8.61 & 4.044 & 6.877 & 1.56 \\
\hline 7 & Pulwama & 63.5 & 44.02 & 30.14 & 6.4 & 4.19 & 4.397 & 6.082 & 1.872 \\
\hline 8 & Shupiyan & 69.69 & 84.86 & 31.97 & 11.64 & 1.82 & 2.924 & 4.314 & 1.125 \\
\hline 9 & Anantnag & 66.34 & 33.53 & 38.00 & 8.64 & 4.62 & 9.769 & 11.787 & 4.826 \\
\hline 10 & Kulgam & 75.22 & 34.58 & 44.00 & 8 & 2.47 & 6.299 & 8.164 & 3.097 \\
\hline
\end{tabular}

Source: Directorate of Economics and Statistical Department (DESD), J \& K, 2011-12 


\section{International Journal of Social Science and Economic Research}

ISSN: $2455-8834$

Volume: 05, Issue: 07 "July 2020"

\section{RESULTS AND DISCUSSION}

Agriculture has been predominant sector in this region and its support around majority of the population. Agricultural growth is essential for any region to alleviate rural poverty, ensure food security and create job opportunities for people living in rural and urban areas.

\section{Map 1: Cultivable Area as Percentage Share of Reporting Area and Area under Commercial Crops as Percentage Share of Gross Area Sown (2011-12)}

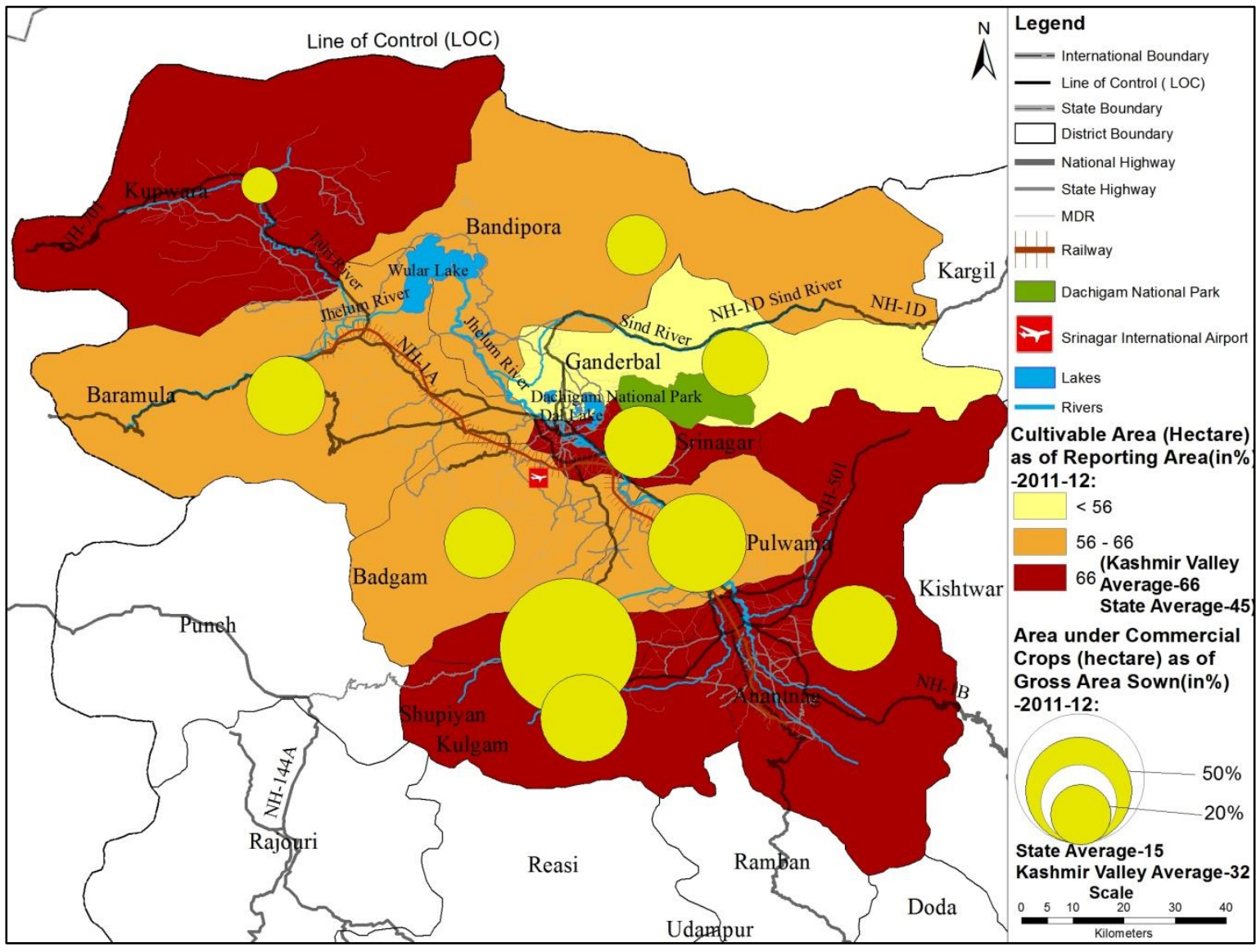

Source: Directorate of Economics and Statistical Department (DESD), J \& K, 2011-12

Cultivable area as percentage share of reporting area is higherthan the State average (45\%) and Kashmir valley average (66\%) in Kupwara, Kulgam, Anantnag, Shupiyan and Srinagar districts. Kupwara emerges as the top level where 72.26 percentage reported area is under cultivation. Kulgam is the next district with 71.72 percentage. The cultivable area across regions indicates 64.92 percentage for Kashmir region, followed by 32.17 percentage and 25.26 percentage in case of Ladakh and Jammu regions respectively. 
Commercial crops are basically cash crops. Rice is the chief crop of this region followed by maize, barley and wheat. The production of three important food crops, namely, rice, maize and wheat, contributes a major portion of the food grains in the Kashmir valley. Shopiyanis emerging as the district where area under commercial crops forms 84.89 percent of gross areas sown. The next major district is Pulwama with 44.09 percent. The regional details of commercial crops reveal that Kashmir region has the highest area i.e., 30.67 percentage of total cropped area under commercial crops, this ratio for Jammu region is far behind with 2.32 percentage and less than 2 percentage for Ladakh region.

\section{Map 2: Net Area Sown as Percentage Share of Geographical Area and Total Percentage Share of Fresh and Dry Fruits Production (2011-12)}

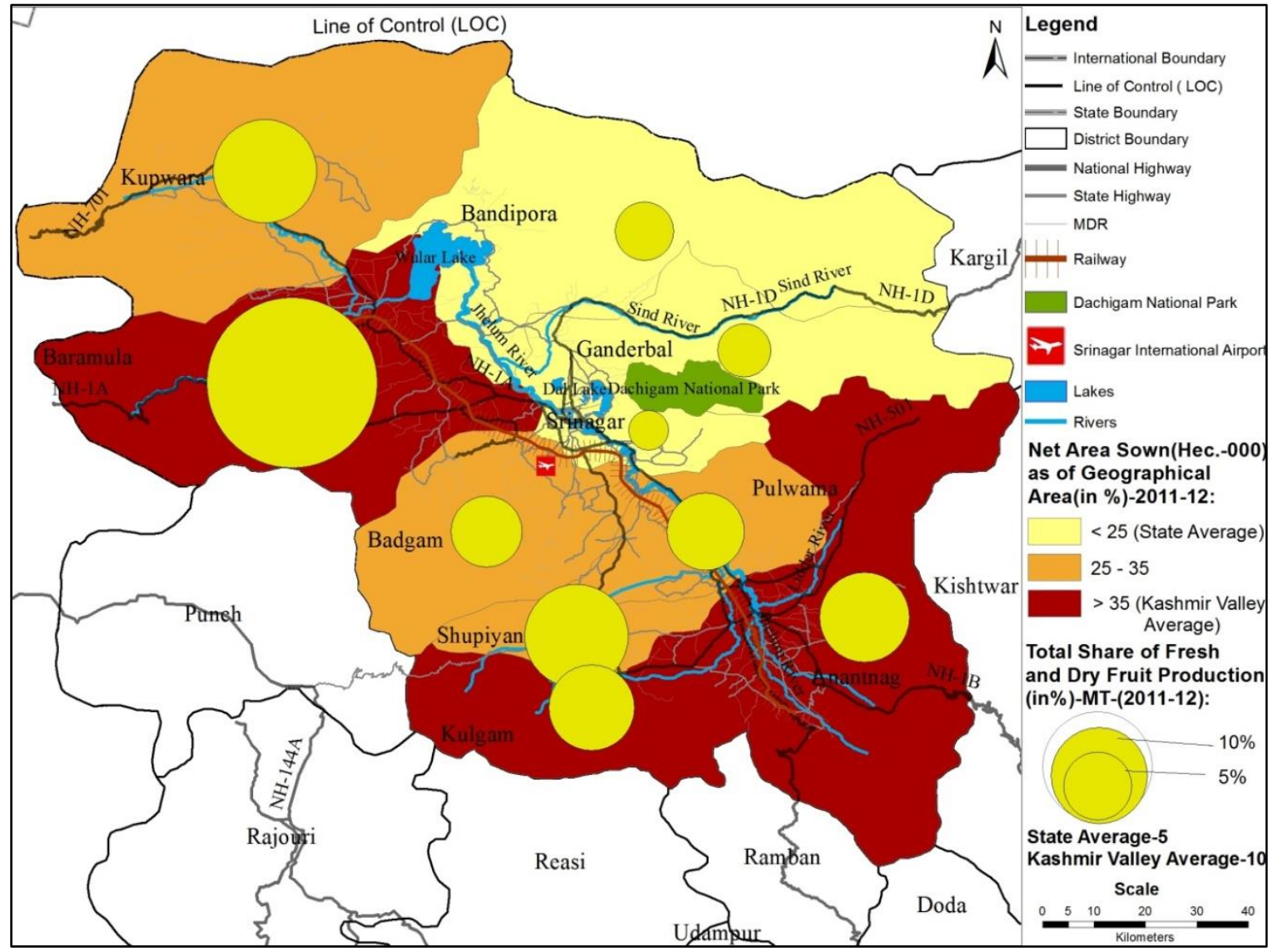

Source: Directorate of Economics and Statistical Department (DESD), $J \& K, 2011-12$

Net areas sown as percentage share of geographical area is high in Baramula, Kulgam, and Anantnag districts. These districts have net sown area percentage share more than the state average (25\%) and Kashmir valley average (35\%). Bandipora and Ganderbal are two districts where the percentage share of net sown area is less than the state average $(25 \%)$. 


\section{International Journal of Social Science and Economic Research}

ISSN: 2455-8834

Volume: 05, Issue: 07 "July 2020"

Kashmir valley is endowed with varied agro-climatic conditions for producing both fresh as well as dry fruits. The export of fresh and dry fruits is leading business of agriculture in this region. Total percentage share of fresh and dry fruits production in metric tonnes are more than the state average (5\%) and Kashmir valley average (10\%) in Baramulla (31.46\%), Shopiyan (11.64\%) and Kupwara (11.45\%) districts. In a regional comparison, Kashmir, which is described as fruit bowl of state, has 90.11 percentage share, the next region is Jammu with 7.20 percentage share and Ladakh with less than 1 percentage share. Though, the country's temperate fruits are grown in this region. There is good scope for the production of high value crops like saffron, black zeera and other spices especially in this valley.

\section{Map 3: Total Percentage Share of Fish Production (2011-12)}

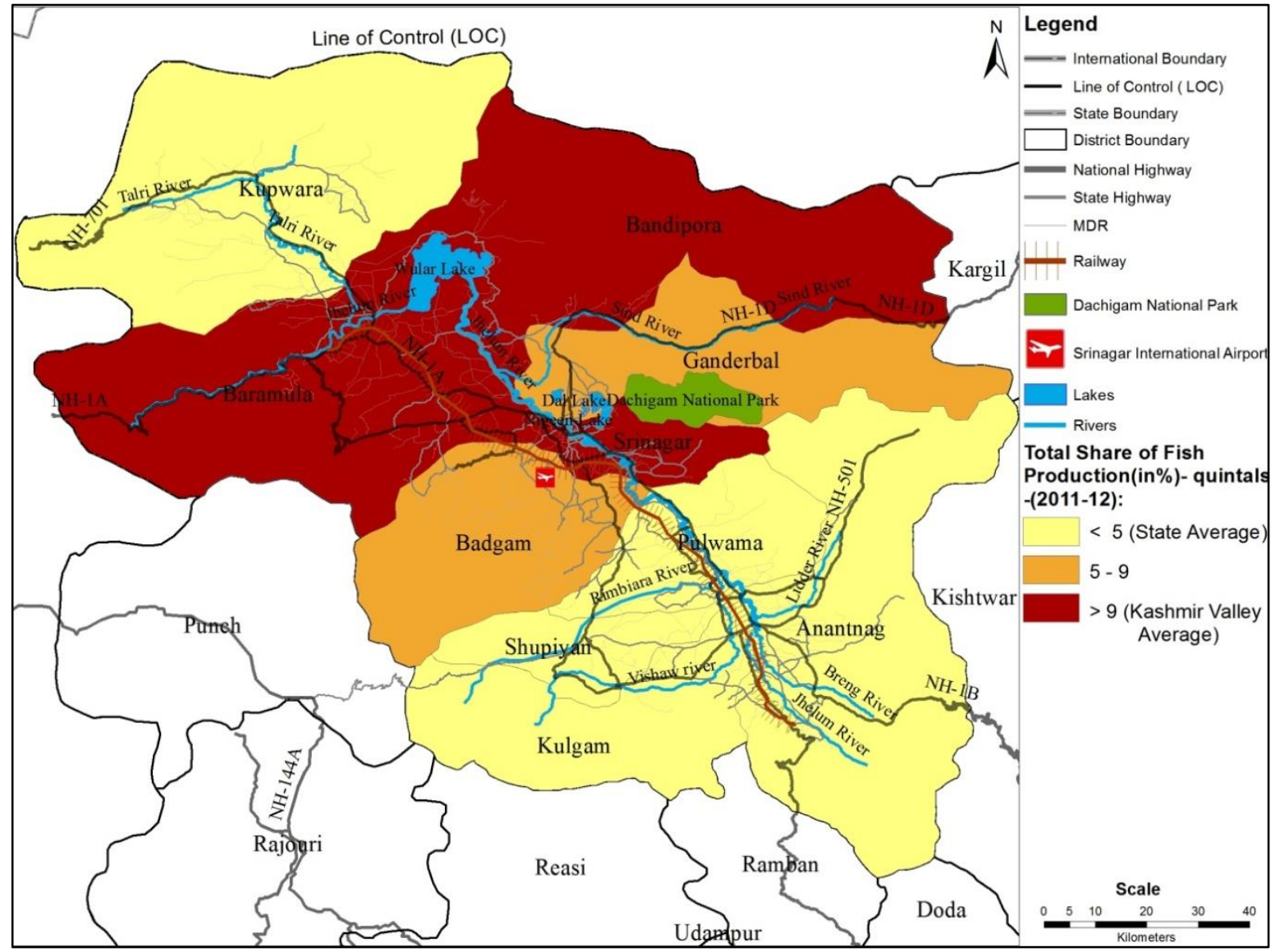

Source: Directorate of Economic and Statistical Department, (DESD), J \& K, 2011-12

Fisheries sector plays an important role in socio-economic development of the Kashmir valley.

It is one of the primary sectors of the state and contribute to the nutritional security, employment generation and state net domestic product. It has a major role and contribution in the livelihood 
source for economically backward population of the state. The domestic product generated in fisheries sector has increased from Rs 4.7 crore in 1980-81 to Rs 361 crore in 2015-16 (Baba, Husain, Zargar, Bhat, \& Malik, 2019). Among the districts, Baramulla (21.99 \%), Bandipora $(17.90 \%)$ and Srinagar $(10.61 \%)$ are the major fish production districts where the total percentage share of fish production are higher than the state $(5 \%)$ and Kashmir valley average (9\%).Although, the percentage share of fish production in the districts of Kulgam, Shupiyan, Anantnag, Pulwama and Kupwara are lower than the state and Kashmir valley average. In fish production, Kashmir valley has a contribution of 82.75 percent, 17 percent of Jammu region and 0.25 percent of Ladakh region only.

\section{Map 4: Total Livestock Population (in lakh) and Total Red Meat production (in lakh kg)-2011 12}

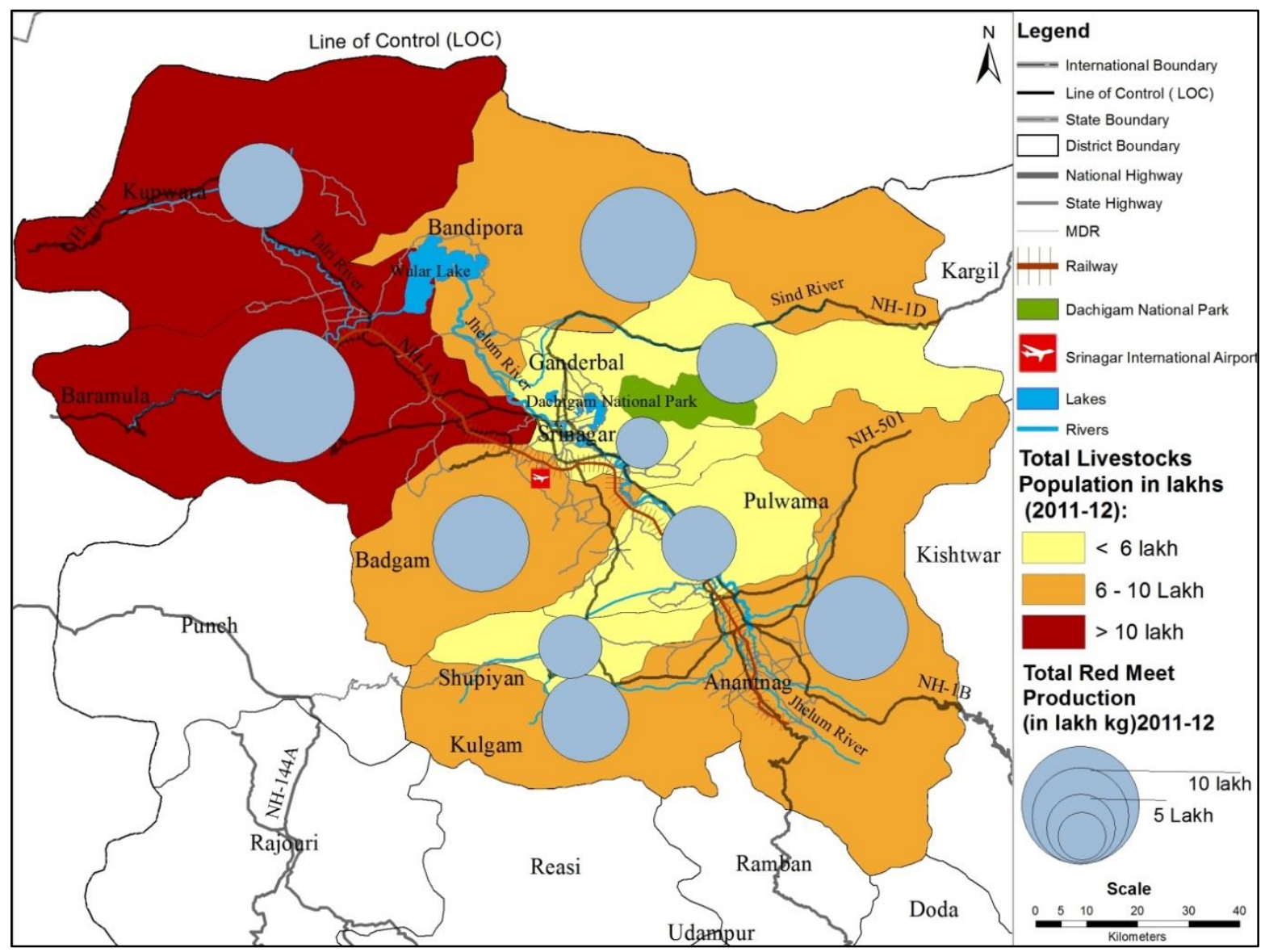

Source: Directorate of Economic and Statistical Department, (DESD), J \& K, 2011-12

The state of Jammu and Kashmir has been traditionally a consumer of meat irrespective of culture, religion and location. Livestock of poultry and cattle are considered the most crucial tool 
for the enhancement of rural economy. Livestock provides supplementary livelihood in the rural areas especially for small, marginal farmers and agricultural labourers who have a low level of land holdings. There were consumed 560 lakh kg of red meat in 2009-2010, of which about twothird was met from domestic production and the rest from imports from other states. About half of the meat production comes from Jammu region, 40 per cent from Kashmir region and rest from Ladakh (Wani, Shaheen, Baba, Naqash, \& Manzoor, 2014). Kupwara and Baramulla are the two districts where the livestock population is more than 10 lakhs. Whereas the livestock population in the districts of Ganderbal, Srinagar, Pulwama and Shupiyan are lower than 6 lakhs. Moreover, Red meat production is predominant in the districts of Baramula, Bandipora, Anantnag, Badgam and Kulgam and produce more than 5 lakh $\mathrm{kg}$ of red meat because of its big livestock population. Red meat is procured in the city of Srinagar from the surrounding regions of Kupwara, Baramulla, Anantnag and Bandipora.

\section{Map 5: Total White Meat Production (in lakh kg-2011-12)}

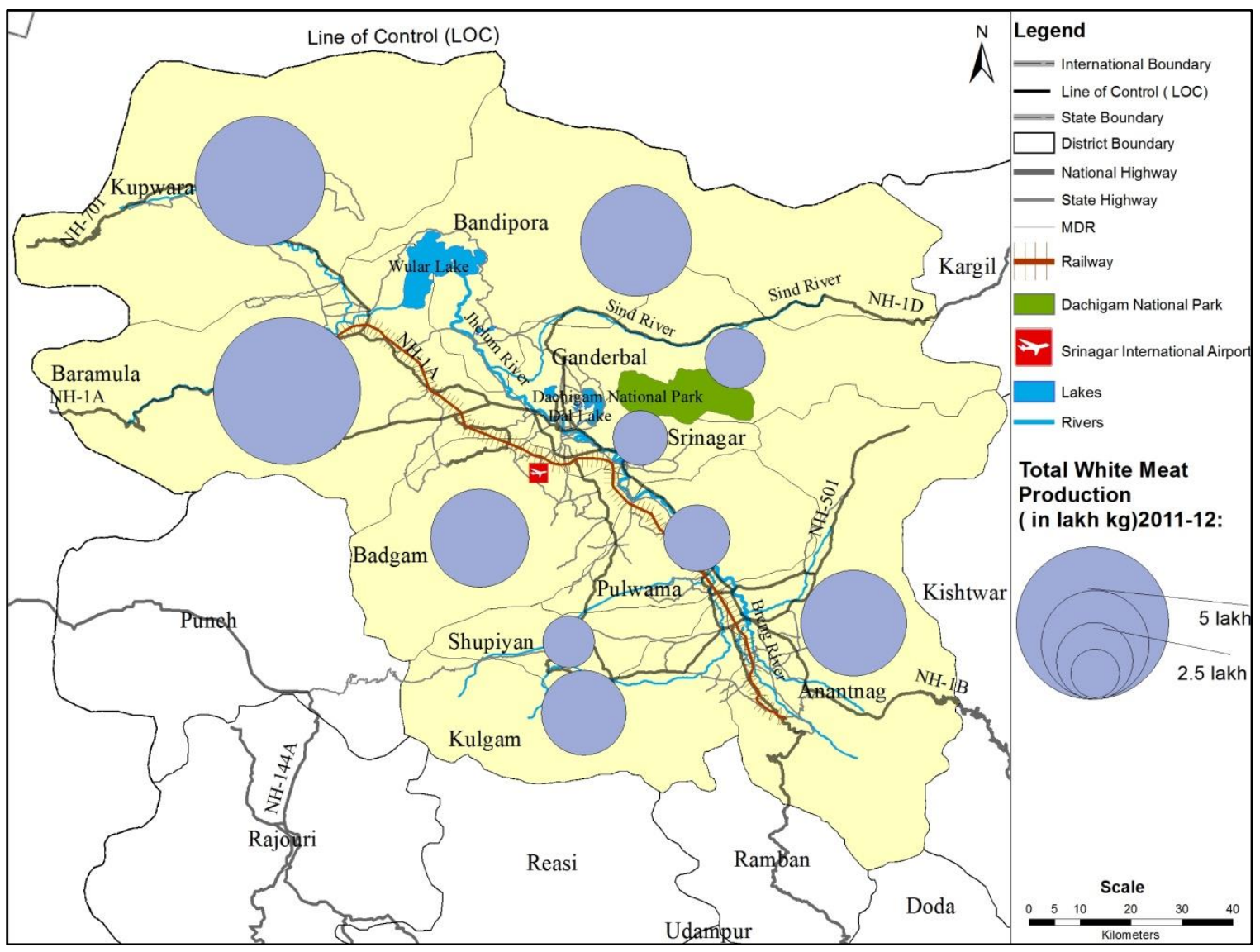

Source: Directorate of Economic and Statistical Department, (DESD), J \& K, 2011-12 
International Journal of Social Science and Economic Research

ISSN: $2455-8834$

Volume: 05, Issue: 07 "July 2020"

Total white meat production is also correlated with livestock population. It is found more in those districts which have more livestock population. Baramula, Kupwara, Bandipora and Anantnag are those districts which had a total white meat production above 4 lakh kg in 2011-12. It is also brought to the respective urban centres of districts from different poultry farms of the state.

\section{ACKNOWLEDGEMENT}

I am extremely thankful to retired prof. Atiya Habeeb Kidwai of C.S.R.D. from Jawaharlal Nehru University for her help and suggestions. I am also grateful to Department of Regional Planning, School of Planning and Architecture, New Delhi.

\section{CONCLUSION}

Agriculture is the key sector of income generation and employment opportunities for the people of Kashmir valley. The urban centers are entirely depended on rural areas in terms of their daily needs and livelihood. There is supposed to be introduced new modern agricultural equipment and technology regarding its cultivation and production techniques. There is needed to increase the investment and incentives in the allied sectors of agriculture like commercial crops, fisheries, horticulture, dairy development, livestock and poultry farming. Similarly, there must be a good governing system to address the issues of agriculture sector in the Kashmir valley.

\section{REFERENCES}

1. Baba, S. H., Husain, N., Zargar, B. A., Bhat, I. F., \& Malik, I. (2019). Growth of fisheries sector in Jammu \& Kashmir. Journal of Pharmacognosy and Phytochemistry, 8(4), 909912.

2. Bhat, M. M. (2013). Agricultural land-use pattern in Pulwama district of Kashmir Valley. International Journal of Economics, Business and Finance, 1(5), 80-93.

3. Census of India. (2011). Primary Census Abstract. India: Office of the Registrar General \& Census Commissioner, Ministry of Home Affairs, Government of India.

4. Digest of Statistics. (2013-14). Retrieved from Directorate of Economics and Statistics, Government of Jammu and Kashmir: http://ecostatjk.nic.in/publications/publications.htm

5. Dixit, J., Sharma, S., \& Ali, M. (2014). Present status, potential and future needs for mechanization of agricultural operations in Jammu and Kashmir state of India. Agricultural Engineering International: CIGR Journal, 16(3), 87-96. Retrieved from http://www.cigrjournal.org 
6. Jeelani, G. H., Shah, R. A., \& Hussain, A. (2014). Hydrogeochemical assessment of groundwater in Kashmir Valley, India. Journal of earth system science, 123(5), 10311043.

7. Planning Commission. (2003). State Development Report. Jammu and Kashmir. New Delhi: Government of India. Retrieved from http://14.139.60.153/handle/123456789/5331

8. Planning Commission. (2012). Twelfth Five Year Plan (2012-2017). Economic Sectors. Volume II.

9. Raina, A. N. (2002). Geography of Jammu \& Kashmir State. Radha Krishan Anand \& Co. Pacca Danga, Jammu.

10. Rather, N. A., Lone, P. A., Reshi, A. A., \& Mir, M. M. (2013). An analytical study on production and export of fresh and dry fruits in Jammu and Kashmir. International Journal of Scientific and Research Publications, 3(2), 1-7.

11. Sharma, R. (2007). Agricultural Development and crop diversification in Jammu and Kashmir: A district level study patterns, processes and determinants. Review of Development and Change, 12(2), 217-251.

12. Sharma, R., Sharma, V. K., \& Waris, V. I. (2012). Impact of peace and disturbances on tourism and horticulture in Jammu and Kashmir. International Journal of Scientific and Research Publications, 2(6), 1-7.

13. Tilman, D., Cassman, K. G., Matsons, P. A., Naylor, R., \& Polasky, S. (2002). Agricultural sustainability and intensive production practices. Nature, 418(6898), 671677.

14. Wani, S., Shaheen, F., Baba, S., Naqash, F., \& Manzoor, M. (2014). Value chains for livestock products in himalayan mountains: studies from Jammu and Kashmir. Indian Journal of Agricultural Economics, 69(3), 280-289. 